\title{
EL ILEGÍTIMO “CONTROL DE CONSTITUCIONALIDAD” DE LAS SENTENCIAS DE LA CORTE INTERAMERICANA DE DERECHOS HUMANOS POR PARTE LA SALA CONSTITUCIONAL DEL TRIBUNAL SUPREMO DE JUSTICIA DE VENEZUELA: EL CASO LEOPOLDO LÓPEZ VS. VENEZUELA, SEPTIEMBRE 2011
}

Allan R. BreWER-CarÍAs ${ }^{1}$

Profesor de la Universidad Central de Venezuela allan@brewercarias.com

\section{INTRODUCCIÓN}

Una de las características fundamentales de la Justicia Constitucional, o del derecho procesal constitucional contemporáneo, es que los Tribunales, como garantes de la Constitución, no sólo tienen que estar sometidos, como todos los órganos del Estado, a las propias previsiones de la Constitución, sino que deben ejercer sus competencias ceñidos a las establecidas en la misma o en las leyes, cuando a ellas remita la Constitución para la determinación de la competencia.

En particular, la competencia de la Jurisdicción Constitucional en materia de control concentrado de la constitucionalidad siempre ha sido considerada como de derecho estricto que tiene que estar establecida expresamente en la Constitución, y no puede ser deducida por vía de interpretación. Es decir, la Jurisdicción Constitucional no puede ser creadora de su propia competencia,

\footnotetext{
* Trabajo elaborado para el Libro Homenaje a Antonio Torres del Moral, Universidad Nacional de Educación a Distancia, Madrid 2012.

${ }^{1}$ Allan Brewer Carías, abogado, doctor en Derecho por la Universidad Central de Venezuela, senador, ministro de Estado para la Descentralización y miembro de la Asamblea Nacional Constituyente de 1999 de Venezuela, en la actualidad ocupa el cargo de profesor adjunto de la Universidad de Columbia de Nueva York. allan@brewercarias.com http://allanbrewercarias.com/
} 
pues ello desquiciaría los cimientos del Estado de derecho, convirtiendo al juez constitucional en poder constituyente. ${ }^{2}$

En el caso de Venezuela, la Sala Constitucional del Tribunal Supremo, como Jurisdicción Constitucional, tiene asignadas las competencias que se enumeran en el artículo 336 de la Constitución y en el artículo 25 de la Ley Orgánica del Tribunal Supremo de Justicia de 2010, no estando prevista en ninguna de esas normas una supuesta competencia para someter a control de constitucionalidad, mediante el ejercicio ante ella de una acción e incluso de oficio, de las sentencias de la Corte Interamericana de Derechos Humanos. Aparte de que ello sería contrario a la Convención Americana de Derechos Humanos, que es de obligatorio cumplimiento mientras el Estado no la denuncie, es contrario al propio texto de la Constitución venezolana que en su artículo 31 prevé como obligación del propio Estado el adoptar, conforme a los procedimientos establecidos en la Constitución y en la ley, "las medidas que sean necesarias para dar cumplimiento a las decisiones emanadas de los órganos internacionales" de protección de derechos humanos.

Sin embargo, la Sala Constitucional del Tribunal Supremo de Justicia mediante sentencia No 1.547 de fecha 17 de octubre de 2011 (Caso Estado Venezolano vs. Corte Interamericana de Derechos Humanos), ${ }^{3}$ procedió a conocer de una "acción innominada de control de constitucionalidad" de la sentencia de la Corte Interamericana de Derechos Humanos dictada en el $1^{\circ}$ de septiembre de 2011 (caso Leopoldo López vs. Estado de Venezuela), que no existe en el ordenamiento constitucional venezolano, ejercida por el Procurador General de la República, condenada en la sentencia.

Dicha sentencia de la Corte Interamericana de Derechos Humanos, por lo demás, había decidido, conforme a la Convención Americana de Derechos Humanos (art. 32.2), que la restricción al derecho pasivo al sufragio (derecho a ser elegido) que se le había impuesto al Sr. Leopoldo López por la Contraloría General de la República de Venezuela mediante una decisión administrativa, no judicial, era contraria a la Convención, pues dichas restricciones a derechos políticos sólo pueden establecerse mediante imposición de una condena dictada mediante sentencia judicial, con las debidas garantías del debido proceso.

\footnotetext{
${ }^{2}$ Véase en general, Brewer-Carías, Allan R. (2011). Constitutional Courts as Positive Legislators in Comparative Law, Cambridge University Press, New York.

${ }^{3}$ Véase en http://www.tsj.gov.ve/decisiones/scon/Octubre/1547-171011-2011-11-1130.htmll
} 
En efecto, el derecho político a ser electo del Sr. Leopoldo López le había sido violado por la Contraloría General de la República, al dictar autos de responsabilidad administrativa contra el mismo aplicando el artículo 105 de la Ley Orgánica de la Contraloría General de la República y del Sistema Nacional de Control Fiscal, imponiéndole mediante actos administrativos la "pena" de inhabilitación política como ex funcionario que es, sancionándolo de manera de restringirle su derecho político al sufragio pasivo que, al contrario, sólo puede ser restringido, acorde con la Constitución (art. 65) y a la Convención Americana de Derechos Humanos (art. 32.2), mediante sentencia judicial que imponga una condena penal.

En tal virtud, el Sr. López recurrió mediante denuncia ante la Comisión Interamericana de Derechos Humanos, para ante la Corte Interamericana de Derechos Humanos, denunciando su derecho, resultando la decisión de esta última condenando al Estado venezolano por violación de dicho derecho al ejercicio pasivo al sufragio en perjuicio del Sr. Leopoldo López, ordenando la revocatoria de las decisiones de la Contraloría General de la República y de otros órganos del Estado que le impedían ejercer su derecho político a ser electo por la inhabilitación política que le había sido impuesta administrativamente.

Debe decirse que ya la Sala Constitucional del Tribunal Supremo, con anterioridad, y en franca violación de la Constitución, ya había resuelto en su sentencia No 1.265 de 5 de agosto de $2008^{4}$ (caso Ziomara Del Socorro Lucena Guédez vs. Contralor General de la República), que el artículo 105 de la Ley Orgánica de la Contraloría General de la República no era violatorio de la Constitución ni de la Convención Americana de Derechos Humanos, admitiendo que mediante ley se podían establecer sanciones administrativas de inhabilitación política contra ex funcionarios, impidiéndoles ejercer su derecho político a ser electos, como era el caso de las decisiones dictadas por la Contraloría General de la República.

En todo caso, frente a la decisión de la Corte Interamericana de Derechos Humanos de condena al Estado Venezolano por violación del derecho político del Sr. Leopoldo López, el Procurador General de la República, como abogado del propio Estado condenado, recurrió ante la Sala Constitucional del Tribunal Supremo solicitándole la revisión judicial por control de constitucionalidad de la misma, de lo cual resultó la sentencia mencionada No 1.547 de 17 de

${ }^{4}$ Véase en http://www.tsj.gov.ve:80/decisiones/scon/Agosto/1265-050808-05-1853.htm 
octubre de 2011 de la Sala Constitucional mediante la cual decidió conocer de una "acción innominada de control de la constitucionalidad" de la sentencia de la Corte Interamericana, y declarar que la sentencia dictada por la misma en protección del Sr. López era "inejecutable" en Venezuela, ratificando así la violación de su derecho constitucional a ser electo, y que le impedía ejercer su derecho a ser electo y ejercer funciones públicas representativas.

Todo esto ha originado una bizarra situación de violación de derechos políticos por parte de los órganos del Estado venezolano, incluyendo la Sala Constitucional del Tribunal Supremo, y de formal desconocimiento de las sentencias dictadas por le Corte Interamericana de Derechos Humanos contra el Estado, a requerimiento del abogado del propio Estado condenado, al declararlas como "inejecutables" en el país.

\section{LA PROTECCIÓN DEL EJERCICIO DEL DERECHO POLÍTICO AL SUFRAGIO PASIVO por parte de la Corte InTERAmericana de Derechos Humanos}

En efecto, la Contraloría General de la República de Venezuela, con ocasión de diversas averiguaciones administrativas abiertas contra el Sr. Leopoldo López Mendoza, quien había sido Alcalde de uno de los Municipios de la capital de la República (Chacao), de conformidad con el artículo 105 de la Ley Orgánica de la Contraloría le impuso diversas sanciones administrativas, y entre ellas, la de inhabilitación para el ejercicio de cargos públicos, afectándole en esa forma su derecho constitucional a ser electo para cargos de elección popular.

El Sr. López presentó denuncia de violación de diversos de sus derechos fundamentales ante la Comisión Interamericana de Derechos Humanos, y esta posteriormente presentó formal demanda contra el Estado Venezolano, denunciando la violación, entre otros, del derecho de ser electo del Sr. Leopoldo López, quién estimó le había sido inflingido por la Contraloría General de la República al imponerle sanciones de inhabilitación en aplicación del artículo 105 de la Ley Orgánica de la Contraloría, y con ocasión de un procedimiento administrativo de averiguaciones administrativas, las cuales le habían impedido a dicho ciudadano registrar su candidatura para cargos de elección popular.

La Corte Interamericana de Derechos Humanos, con fecha 1 de septiembre de 2011 dictó sentencia (caso López Mendoza vs. Venezuela) (Fondo, Reparaciones y Costas), en la cual, entre las múltiples violaciones denunciadas, se 
refirió específicamente a la violación del derecho político a ser electo, para lo cual pasó a determinar

"si las sanciones de inhabilitación impuestas al señor López Mendoza por decisión de un órgano administrativo y la consiguiente imposibilidad de que registrara su candidatura para cargos de elección popular" eran o no compatibles con la Convención Americana de derechos Humanos" (Párr. 104).

A tal efecto, la Corte Interamericana constató que el artículo 23.1 de la Convención establece que todos los ciudadanos deben gozar de los siguientes derechos y oportunidades, los cuales deben ser garantizados por el Estado en condiciones de igualdad:

“i) a la participación en la dirección de los asuntos públicos, directamente o por representantes libremente elegidos;

ii) a votar y a ser elegido en elecciones periódicas auténticas, realizadas por sufragio universal e igual y por voto secreto que garantice la libre expresión de los electores, $y$

iii) a acceder a las funciones públicas de su país"(Párr. 106).

Estos derechos, como todos los que consagra la Convención, es bueno recordarlo, al decir de la Sala Constitucional del Tribunal Supremo de Venezuela, conforman:

"una declaración de principios, derechos y deberes de corte clásico que da preeminencia a los derechos individuales, civiles y políticos dentro de un régimen de democracia formal. Obviamente, como tal, es un texto que contiene una enumeración de libertades de corte liberal que son valiosas para garantizar un régimen que se oponga a las dictaduras que han azotado nuestros países iberoamericanos desde su independencia". ${ }^{5}$

Por otra parte, la Corte Interamericana precisó que en artículo 23.2 de la Convención es el que determina cuáles son las causales que permiten restringir

\footnotetext{
5 Véase sentencia No 1.265/2008 dictada el 5 de agosto de 2008, en http://www.tsj.gov.ve:80/decisiones/ scon/Agosto/1265-050808-05-1853.htm. La Sala, sin embargo, en la misma sentencia se lamentaba que en la Convención no había "norma alguna sobre derechos sociales (solo hay una declaración de principios acerca de su desarrollo progresivo en el artículo 26), ni tampoco tiene previsión sobre un modelo distinto al demócrata liberal, como lo es la democracia participativa, ni contempla un tipo de Estado que en lugar de construir sus instituciones en torno al individuo, privilegie la sociedad en su conjunto, dando lugar a un Estado social de derecho y de justicia”. Idem.
} 
los derechos antes indicados reconocidos en el artículo 23.1, así como, en su caso, los requisitos que deben cumplirse para que proceda tal restricción.

Ahora bien, en el caso sometido a su consideración, que se refería "a una restricción impuesta por vía de sanción”, la CIDH consideró que debería tratarse de una "condena, por juez competente, en proceso penal", estimando que en el caso:

"ninguno de esos requisitos se ha cumplido, pues el órgano que impuso dichas sanciones no era un 'juez competente', no hubo 'condena' y las sanciones no se aplicaron como resultado de un 'proceso penal', en el que tendrían que haberse respetado las garantías judiciales consagradas en el artículo 8 de la Convención Americana" (Párr. 107).

La Corte Interamericana, en su decisión, reiteró su criterio de que "el ejercicio efectivo de los derechos políticos constituye un fin en sí mismo y, a la vez, un medio fundamental que las sociedades democráticas tienen para garantizar los demás derechos humanos previstos en la Convención y que sus titulares", es decir, los ciudadanos, no sólo deben gozar de derechos, sino también de "oportunidades"; término este último que implica, al decir de la Corte Interamericana, "la obligación de garantizar con medidas positivas que toda persona que formalmente sea titular de derechos políticos tenga la oportunidad real para ejercerlos". En el caso decidido en la sentencia, la Corte Interamericana precisamente consideró que "si bien el señor López Mendoza ha podido ejercer otros derechos políticos, está plenamente probado que se le ha privado del sufragio pasivo, es decir, del derecho a ser elegido" (Párr. 108).

Fue en virtud de los anteriores argumentos que la Corte Interamericana determinó que el Estado venezolano violó los artículos 23.1.b y 23.2 en relación con el artículo 1.1 de la Convención Americana, en perjuicio de Leopoldo López Mendoza (Párr. 109), concluyendo que:

"el Estado es responsable por la violación del derecho a ser elegido, establecido en los artículos 23.1.b y 23.2, en relación con la obligación de respetar y garantizar los derechos, establecida en el artículo 1.1 de la Convención Americana sobre Derechos Humanos, en perjuicio del señor López Mendoza, en los términos del párrafo 109 de la presente Sentencia” (Párr. 249).

Por otra parte, la Comisión Interamericana había solicitado la Corte Interamericana que se ordenase al Estado el adoptar las medidas necesarias para reestablecer los derechos políticos del señor Leopoldo López Mendoza 
(Párr. 214), sobre lo cual sus representantes solicitaron la restitución plena en el ejercicio de su "derecho político a ser electo" según el artículo 23 de la Convención, a fin de poder presentarse "como candidato en las elecciones que se celebren en la República Bolivariana de Venezuela", solicitando además, que se dejasen sin efecto "las decisiones de inhabilitación dictadas por la Contraloría General de la República y por las distintas ramas del Poder Público Nacional "en el marco de las inhabilitaciones políticas administrativas", y que se requiriera al Estado que el Consejo Nacional Electoral permitiera su inscripción y postulación electoral para cualquier proceso de elecciones a celebrarse en Venezuela (Párr. 214).

Sobre esto, y en virtud de considerar que en el caso se habían violado los artículos 23.1.b, 23.2 y 8.1, en relación con los artículos 1.1 y 2 de la Convención Americana (supra párrs. 109, 149, 205 y 206), la CIDH declaró que:

"el Estado, a través de los órganos competentes, y particularmente del Consejo Nacional Electoral (CNE), debe asegurar que las sanciones de inhabilitación no constituyan impedimento para la postulación del señor López Mendoza en el evento de que desee inscribirse como candidato en procesos electorales a celebrarse con posterioridad a la emisión de la presente Sentencia" (Párr. 217).

Consecuencialmente, la CIDH declaró que el Estado debía "dejar sin efecto las Resoluciones Nos. 01-00-000206 de 24 de agosto de 2005 y 01-00-000235 de 26 de septiembre de 2005 emitidas por el Contralor General de la República (supra párrs. 58 y 81), mediante las cuales se declaró la inhabilitación para el ejercicio de funciones públicas del señor López Mendoza por un período de 3 y 6 años, respectivamente" (Párr. 218), concluyendo en la parte final del fallo, con las siguientes dos disposiciones:

“2. El Estado, a través de los órganos competentes, y particularmente del Consejo Nacional Electoral (CNE), debe asegurar que las sanciones de inhabilitación no constituyan impedimento para la postulación del señor López Mendoza en el evento de que desee inscribirse como candidato en procesos electorales a celebrarse con posterioridad a la emisión de la presente Sentencia, en los términos del párrafo 217 del presente Fallo";

"3. El Estado debe dejar sin efecto las Resoluciones Nos. 01-00-000206 de 24 de agosto de 2005 y 01-00-000235 de 26 de septiembre de 2005 emitidas por el Contralor General de la República, en los términos del párrafo 218 del presente Fallo". 


\section{Sobre LA “ACCiÓn INNOMINADA DE CONTROL DE CONSTITUCIONALIDAD” DE LAS SENTENCIAS DE LA CORTE INTERAMERICANA de Derechos Humanos y su trámite}

Contra la antes mencionada sentencia dictada por la Corte Interamericana de Derechos Humanos el 1 de septiembre de 2011, algo más de tres semanas después, el día 26 de septiembre de 2011, el Procurador General de la República, actuando en representación del Estado venezolano, interpuso ante la Sala Constitucional del Tribunal Supremo de Justicia lo que denominó como una "acción innominada de control de constitucionalidad", la cual la Sala, sin competencia alguna para ello y en franca violación de la Constitución, pasó a conocer de inmediato, decidiéndola en sólo veinte días mediante sentencia No 1.547 (Caso Estado venezolano vs. Corte Interamericana de Derechos Humanos) de fecha 17 de octubre de $2011 .^{6}$

El Procurador General de la República, al intentar la acción, justificó la supuesta competencia de la Sala Constitucional en su carácter de "garante de la supremacía y efectividad de las normas y principios constitucionales" (arts. 266.1, 334, 335 y 336 de la Constitución, el artículo 32 de la Ley Orgánica del Tribunal Supremo de Justicia), considerando básicamente que la República, ante una decisión de la Corte Interamericana de Derechos Humanos, no podía dejar de realizar "el examen de constitucionalidad en cuanto a la aplicación de los fallos dictados por esa Corte y sus efectos en el país", considerando en general que las decisiones de dicha Corte Interamericana sólo pueden tener "ejecutoriedad en Venezuela", en la medida que "el contenido de las mismas cumplan el examen de constitucionalidad y no menoscaben en forma alguna directa o indirectamente el Texto Constitucional"; es decir, que dichas decisiones "para tener ejecución en Venezuela deben estar conformes con el Texto Fundamental".

Luego de analizar la sentencia de la Corte Interamericana, y referirse al carácter de los derechos políticos como limitables; y a la competencia de la Contraloría General de la República, conforme al artículo 105 de su Ley Orgánica, para garantizar una "Administración recta, honesta, transparente en el manejo de los asuntos públicos, dotada de eficiencia y eficacia en la actividad administrativa en general, y especialmente en los servicios públicos" y para imponer "la sanción de suspensión, destitución e inhabilitación para

\footnotetext{
${ }^{6}$ Véase en http://www.tsj.gov.ve/decisiones/scon/Octubre/1547-171011-2011-11-1130.htmll
} 
el ejercicio de funciones públicas"; la Sala pasó a considerar que lo que la Contraloría le había impuesto al Sr. Leopoldo López había sido una "inhabilitación administrativa" y no una inhabilitación política que se "corresponde con las sanciones que pueden ser impuestas por un juez penal, como pena accesoria a la de presidio (artículo 13 del Código Penal)", y que las decisiones adoptadas por la Corte Interamericana con órdenes dirigidas a órganos del Estado "se traduce en una injerencia en las funciones propias de los poderes públicos", estimando que la Corte Interamericana no puede "valerse o considerarse instancias superiores ni magnánimas a las autoridades nacionales, con lo cual pretendan obviar y desconocer el ordenamiento jurídico interno, todo ello en razón de supuestamente ser los garantes plenos y omnipotentes de los derechos humanos en el hemisferio americano": y en fin, estimar que la sentencia de la Corte Interamericana de Derechos Humanos desconocía "la lucha del Estado venezolano contra la corrupción y la aplicación de la Convención Interamericana contra la Corrupción, ratificada por Venezuela el 2 de junio de 1997 y la Convención de las Naciones Unidas contra la Corrupción, ratificada el 2 de febrero de 2009”. Después de todo ello, el Procurador General de la República consideró que la mencionada sentencia de la Corte Interamericana transgredía el ordenamiento jurídico venezolano, pues desconocía:

"la supremacía de la Constitución y su obligatoria sujeción, violentando el principio de autonomía de los poderes públicos, dado que la misma desconoce abiertamente los procedimientos y actos legalmente dictados por órganos legítimamente constituidos, para el establecimiento de medidas y sanciones contra aquellas actuaciones desplegadas por la Contraloría General de la República que contraríen el principio y postulado esencial de su deber como órgano contralor, que tienen como fin último garantizar la ética como principio fundamental en el ejercicio de las funciones públicas".

Como consecuencia de ello, el Procurador General de la República solicitó de la Sala Constitucional que admitiera lo que llamó la "acción innominada de control de constitucionalidad", a los efectos de que la Sala declarase "inejecutable e inconstitucional la sentencia de la Corte Interamericana de Derechos Humanos del 1 de septiembre de 2011".

Sobre esta "nueva" acción propuesta por el Procurador para el control de constitucionalidad de sentencias dictadas en contra del Estado por la Corte Interamericana, la Sala Constitucional aclaró en su sentencia que el Procurador no pretendía que se declarase "la nulidad" ni de la Convención Americana 
de Derechos Humanos ni del fallo de la Corte Interamericana de Derechos Humanos, aclarando por ello, la propia Sala, que por tanto, la "acción innominada intentada" no era un "recurso de nulidad como mecanismo de control concentrado de la constitucionalidad” el cual consideró la Sala que no resultaba idóneo.

La Sala, por otra parte, también descartó que se tratase de una acción de "colisión de leyes",

"pues de lo que se trata es de una presunta controversia entre la Constitución y la ejecución de una decisión dictada por un organismo internacional fundamentada en normas contenidas en una Convención de rango constitucional, lo que excede los límites de ese especial recurso, pues la presunta colisión estaría situada en el plano de dos normas de rango constitucional".

Luego de descartar esas hipótesis de acciones de nulidad o de colisión de leyes, y precisar que de lo que se trataba con la acción intentada era determinar la "controversia entre la Constitución y la ejecución de una decisión dictada por un organismo internacional", concluyó, en definitiva, que de lo que se trataba era de una acción mediante la cual se pretendía:

"ejercer un 'control innominado de constitucionalidad', por existir una aparente antinomia entre la Constitución de la República Bolivariana de Venezuela, la Convención Interamericana de Derechos Humanos, la Convención Americana contra la Corrupción y la Convención de las Naciones Unidas contra la Corrupción, producto de la pretendida ejecución del fallo dictado el 1 de septiembre de 2011, por la Corte Interamericana de Derechos Humanos (CIDH), que condenó a la República Bolivariana de Venezuela a la habilitación para ejercer cargos públicos al ciudadano Leopoldo López Mendoza”.

Es bien sabido en el mundo de la justicia constitucional, que el juez constitucional como todo órgano del Estado está, ante todo, sometido a la Constitución, por lo que debe ceñirse a ella no sólo en la emisión de sus sentencias, sino en el ejercicio de sus propias competencias. Para que el juez constitucional sea garante de la Constitución tiene que ejercer las competencias que la Constitución le atribuye, pues de lo contrario si ejerciera competencias distintas estaría actuando como Poder Constituyente, modificando la propia Constitución, en violación a la misma. Eso es precisamente lo que ha ocurrido en este caso, al "inventar" la Sala Constitucional una nueva acción para el control de constitucionalidad, siguiendo la orientación que ya había sentado 
en otros casos, como cuando "inventó" la acción autónoma y directa de interpretación abstracta de la Constitución mediante sentencia No 1.077 de 22 de septiembre de 2000 (Caso: Servio Tulio León) ${ }^{7}$ lo cual por lo demás cita con frecuencia en su sentencia. En aquella ocasión y en esta la Sala Constitucional actuó como poder constituyente al margen de la Constitución. ${ }^{8}$

Ahora bien, en el caso concreto, identificado el objeto de la acción "innominada" que intentó el Estado Venezolano ante la Sala Constitucional, la misma consideró que le correspondía en "su condición de último intérprete de la Constitución", realizar "el debido control de esas normas de rango constitucional" y ponderar "si con la ejecución del fallo de la CIDH se verifica tal confrontación".

Para determinar el "alcance" de esta "acción de control constitucional" la Sala Constitucional recordó, por otra parte, que ya lo había hecho en anterior oportunidad, al "conocer sobre la conformidad constitucional" del fallo de la Corte Interamericana de Derechos Humanos (CIDH) en sentencia No 1939 de 18 de diciembre de 2008 (caso: Estado Venezolano vs. Corte Interamericana de derechos Humanos, caso Magistrados de la Corte Primera de lo Contencioso Administrativo), ${ }^{9}$ mediante la cual "asumió la competencia con base en la sentencia 1077/2000 y según lo dispuesto en el cardinal 23 del artículo 5 de la Ley Orgánica del Tribunal Supremo de Justicia de 2004". ${ }^{10}$

Ahora bien, en virtud de que esta previsión legal atributiva de competencia desapareció de la nueva Ley Orgánica del Tribunal Supremo de Justicia de 2010, lo que significaba que "la argumentación de la Sala Constitucional para asumir la competencia para conocer de la conformidad constitucional

\footnotetext{
7 Véase en Revista de Derecho Público, No 83, Editorial Jurídica Venezolana, Caracas 2000, pp. 247 y ss.

${ }^{8}$ Véase Daniela Urosa M, Maggi, La Sala Constitucional del Tribunal Supremo de Justicia como Legislador Positivo, Academia de Ciencias Políticas y Sociales, Serie Estudios No 96, Caracas 2011. Véase nuestro "Prólogo" a dicho libro, "Los tribunales constitucionales como legisladores positivos. Una aproximación comparativa”, pp. 9-70.

9 Véase en Revista de Derecho Público, No 116, Editorial Jurídica venezolana, Caracas 2008, pp. 88 y ss.

${ }^{10}$ En dicha norma de la Ley de 2004 se disponía como competencia de la Sala: "Conocer de las controversias que pudieran suscitarse con motivo de la interpretación y ejecución de los Tratados, Convenios o Acuerdos Internacionales suscritos y ratificados por la República. La sentencia dictada deberá ajustarse a los principios de justicia internacionalmente reconocidos y será de obligatorio cumplimiento por parte del Estado venezolano".
} 
de un fallo dictado por la Corte Interamericana de Derechos Humanos", había "sufrido un cambio" al no estar incluida en dicha previsión atributiva de competencia en el artículo 25 de la nueva Ley Orgánica, la Sala, en ausencia de una previsión legal expresa que contemplase "esta modalidad de control concentrado de la constitucionalidad", pasó a:

“invocar la sentencia No 1.077/2000, la cual sí prevé esta razón de procedencia de interpretación constitucional, a los efectos de determinar el alcance e inteligencia de la ejecución de una decisión dictada por un organismo internacional con base en un tratado de jerarquía constitucional, ante la presunta antinomia entre la Convención Interamericana de Derechos Humanos y la Constitución Nacional".

Debe recordarse que la mencionada sentencia "invocada" No 1.077/2000, fue la dictada en 22 de septiembre de 2000 (Caso Servio Tulio León Briceño) en la cual, la Sala, sin competencia constitucional ni legal alguna, y sólo como resultado de la función interpretativa que el artículo 335 de la Constitución le atribuye, "inventó" la existencia de un recurso autónomo de interpretación abstracta de la Constitución. ${ }^{11}$

Por ello, la Sala en este caso hizo la "invocación" a dicha sentencia, pasando luego a comentar la competencia establecida en el artículo 335 de la Constitución, la cual en realidad, es una competencia que se atribuye al todo el Tribunal Supremo de Justicia, en todas sus Salas -y no sólo a la Sala Constitucional-, que es la competencia general de garantizar "la supremacía y efectividad de las normas y principios constitucionales", para lo cual el Tribunal Supremo en su totalidad -y no sólo la Sala Constitucional- se lo define como "el máximo y último intérprete de la Constitución" correspondiéndole velar "por su uniforme interpretación y aplicación”.

\footnotetext{
${ }^{11}$ Véase sobre esta sentencia los comentarios en Marianella Villegas Salazar, "Comentarios sobre el recurso de interpretación constitucional en la jurisprudencia de la Sala Constitucional”, en Revista de Derecho Público, No 84, Editorial Jurídica Venezolana, Caracas 2000, pp. 417 y ss.; y Allan R. BrewerCarías, "Le recours d'interprétation abstrait de la Constitution au Vénézuéla", en Le renouveau du droit constitutionnel, Mélanges en l'honneur de Louis Favoreu, Dalloz, Paris, 2007, pp. 61-70, y "Quis Custodiet Ipsos Custodes: De la interpretación constitucional a la inconstitucionalidad de la interpretación”, en Revista de Derecho Público, No 105, Editorial Jurídica Venezolana, Caracas 2006, pp. 7-27, y en VIII Congreso Nacional de derecho Constitucional, Perú, Fondo Editorial 2005, Colegio de Abogados de Arequipa, Arequipa, septiembre 2005, pp. 463-489. Este último trabajo fue también recogido en el libro Allan R. Brewer-Carías, Crónica sobre la "In" Justicia Constitucional. La Sala Constitucional y el autoritarismo en Venezuela, Colección Instituto de Derecho Público. Universidad Central de Venezuela, No 2, Editorial Jurídica Venezolana, Caracas 2007, pp. 47-79.
} 
De manera que recordando la "invención" de ese recurso autónomo de interpretación abstracta de la Constitución, la Sala pasó a constatar, sin embargo, que el Legislador había eliminado la previsión antes indicada establecida en el artículo 5.23 de la Ley Orgánica del Tribunal Supremo de Justicia de 2004 que la Sala también había "invocado" para decidir el caso mencionado de la inejecución de la sentencia de la Corte Interamericana condenando al Estado por violación de los derechos de los magistrados de la Corte Primera de lo Contencioso Administrativo; y desconociendo esa expresa voluntad del Legislador de eliminar dicha norma del ordenamiento jurídico, pasó a constatar que el propio Legislador no había "dictado las normas adjetivas que permitan la adecuada implementación de las "decisiones emanadas de los órganos internacionales" de conformidad con lo previsto en el artículo 31 constitucional (en su único aparte)", afirmando entonces de oficio, que:

"el Estado (y, en concreto, la Asamblea Nacional) ha incurrido en una omisión "de dictar las normas o medidas indispensables para garantizar el cumplimiento de esta Constitución...", a tenor de lo previsto en el artículo 336.7 eiusdem en concordancia con lo pautado en la Disposición Transitoria Sexta del mismo texto fundamental".

Es decir, la Sala Constitucional, no sólo desconoció la voluntad del Legislador en eliminar una norma del ordenamiento jurídico, sino que calificó dicha decisión como una "omisión de la Asamblea Nacional de dictar las normas necesarias para dar cumplimiento a las decisiones de los organismos internacionales y/o para resolver las controversias que podrían presentarse en su ejecución”, siendo la consecuencia de ello, la declaratoria de la Sala, de oficio, de asumir la competencia, que ni la Constitución ni la ley le atribuyen:

"para verificar la conformidad constitucional del fallo emitido por la Corte Interamericana de Derechos Humanos, control constitucional que implica lógicamente un "control de convencionalidad" (o de confrontación entre normas internas y tratados integrantes del sistema constitucional venezolano), lo cual debe realizar en esta oportunidad esta Sala Constitucional, incluso de oficio; y así se decide".

En esta forma quedó formalizada por voluntad de la Sala, la "invención" de una nueva modalidad de control de constitucionalidad, la cual puede tener su origen en una acción, pero que la Sala declaró que también 
podría ejercer de oficio. No es esta, sin embargo, la primera vez que la Sala Constitucional muta la Constitución específicamente en materia de justicia constitucional. ${ }^{12}$

En cuanto a la "acción" intentada por el Procurador en este caso, la Sala Constitucional la admitió pura y simplemente, pasando a disponer que como no se trataba de una "demanda" de interpretación de normas o principios del sistema constitucional (artículo 25.17 de la Ley Orgánica del Tribunal Supremo de Justicia), "sino de una modalidad innominada de control concentrado que requiere de la interpretación para determinar la conformidad constitucional de un fallo", la Sala, con fundamento en el artículo 98 de la Ley Orgánica del Tribunal Supremo de Justicia, en concordancia con el párrafo primero del artículo 145 eiusdem, determinó que "al tratarse de una cuestión de mero derecho", la causa no requería de sustanciación, ignorando incluso el escrito presentado por el Sr. López, entrando a decidir la causa "sin trámite y sin fijar audiencia oral para escuchar a los interesados ya que no requiere el examen de ningún hecho", incluso, "omitiéndose asimismo la notificación a la Fiscalía General de la República, la Defensoría del Pueblo y los terceros interesados", todo ello, a juicio de la Sala, "en razón de la necesidad de impartir celeridad al pronunciamiento por la inminencia de procesos de naturaleza electoral, los cuales podrían ser afectados por la exigencia de ejecución de la sentencia objeto de análisis". La violación al debido proceso y a la necesaria contradicción del proceso constitucional fue evidente, sólo explicable por la urgencia de decidir y complacer al poder.

Quedó en esta forma "formalizada" en la jurisprudencia de la Sala Constitucional en Venezuela, actuando como Jurisdicción Constitucional, y sin tener competencia constitucional alguna para ello, la existencia de una "acción innominada de control de constitucionalidad" destinada a revisar las sentencias de la Corte Interamericana de Derechos Humanos. Es decir, el Estado venezolano, con esta sentencia, estableció un control de las sentencias que la Corte Interamericana pueda dictar contra el mismo Estado condenán-

\footnotetext{
${ }^{12}$ Véase BREWER-CARÍAS, Allan R. "La ilegítima mutación de la constitución por el juez constitucional: la inconstitucional ampliación y modificación de su propia competencia en materia de control de constitucionalidad. Trabajo elaborado para el Libro Homenaje a Josefina Calcaño de Temeltas. Fundación de Estudios de Derecho Administrativo (FUNEDA), Caracas 2009, pp. 319-362; "La ilegítima mutación de la Constitución por el juez constitucional y la demolición del Estado de derecho en Venezuela"., en Revista de Derecho Político, No 75-76, Homenaje a Manuel García Pelayo, Universidad Nacional de Educación a Distancia, Madrid, 2009, pp. 291-325.
} 
dolo por violación de derechos humanos, cuya ejecución en relación con el Estado condenado, queda a su sola voluntad, determinada por su Tribunal Supremo de Justicia a su propia solicitud (del Estado condenado) a través del Procurador General de la República. Se trata, en definitiva, de un absurdo sistema de justicia en el cual el condenado en una decisión judicial es quien determina si la condena que se le ha impuesto es o no ejecutable. Eso es la antítesis de la justicia.

III. EL TEMA DE LA JERARQUÍA CONSTITUCIONAL DE LOS TRATADOS SOBRE DERECHOS HUMANOS, LA NEGACIÓN DEL PODER DE LOS JUECES A DECIDIR SU APLICACIÓN PREFERENTE, Y EL MONOPOLIO DEL CONTROL DE CONSTITUCIONALIDAD ASUMIDO POR LA SALA RESPECTO DE LAS DECISIONES DE LA CORTE INTERAMERICANA

La Sala Constitucional del Tribunal Supremo en fecha 17 de octubre de 2011, en franca violación de la Constitución, pasó a conocer de inmediato la "acción innominada intentada por el Procurador General de la República en nombre del Estado condenado, la cual fue decidida en sólo veinte días mediante sentencia No 1.547 (Caso Estado Venezolano vs. Corte Interamericana de Derechos Humanos), ${ }^{13}$ en la cual entre las "motivaciones para decidir", la Sala pasó a analizar la sentencia de la Corte Interamericana de Derechos Humanos de 1 de septiembre de 2011, en la cual, como se dijo, la Corte Interamericana declaró responsable internacionalmente al Estado "por haber presuntamente vulnerado el derecho político a ser elegido (sufragio pasivo) del ciudadano Leopoldo López Mendoza con base en unas sanciones de inhabilitación de tres (3) y seis (6) años para el ejercicio de funciones públicas que le fueron impuestas por el Contralor General de la República”; y en la cual la Corte Interamericana resolvió el caso "mediante la aplicación de lo dispuesto por el artículo 23 de la Convención Americana, porque se trata de sanciones que impusieron una restricción al derecho a ser elegido, sin ajustarse a los requisitos aplicables de conformidad con el párrafo 2 del mismo, relacionado con "una condena, por juez competente, en proceso penal" (destacado de la Sala).

Entre los primeros párrafos de la sentencia de la Corte Interamericana que se sometió a revisión judicial, la Sala Constitucional destacó lo siguiente sobre el rango constitucional y la fuerza obligatoria de los Convenios internacio-

${ }^{13}$ Véase en http://www.tsj.gov.ve/decisiones/scon/Octubre/1547-171011-2011-11-1130.htmll 
nales en materia de derechos humanos en el derecho interno, como lo indica el artículo 23 de la Constitución, ${ }^{14}$ y la obligación de los jueces de ejercer el control de convencionalidad para asegurar su aplicación, en el cual la Corte Interamericana dijo:

"Pero cuando un Estado es parte de un tratado internacional como la Convención Americana, todos sus órganos, incluidos sus jueces y demás órganos vinculados a la administración de justicia, también están sometidos a aquél, lo cual les obliga a velar para que los efectos de las disposiciones de la Convención no se vean mermadas por la aplicación de normas contrarias a su objeto y fin. Los jueces y órganos vinculados a la administración de justicia en todos sus niveles están en la obligación de ejercer ex officio un 'control de convencionalidad', entre las normas internas y la Convención Americana, en el marco de sus respectivas competencias y de las regulaciones procesales correspondientes. En esta tarea, los jueces y órganos vinculados a la administración de justicia deben tener en cuenta no solamente el tratado, sino también la interpretación que del mismo ha hecho la Corte Interamericana, intérprete última de la Convención Americana”. (destacado nuestro)

Esta última afirmación de la Corte Interamericana, que copió la Sala Constitucional en su sentencia, sin embargo, en la misma fue abiertamente contradicha, cuestionando la Sala cualquier valor o jerarquía constitucional que conforme al artículo 23 de la Constitución puedan tener las propias sentencias de la Corte Interamericana.

En efecto, sobre el tema de la jerarquía constitucional de los tratados internacionales en materia de derechos humanos conforme a la mencionada norma del artículo 23 de la Constitución, la Sala Constitucional acudió a lo que ya había decidido anteriormente en su sentencia No 1.942 de 15 de julio de 2003 (Caso: Impugnación artículos del Código Penal sobre leyes de desacato), ${ }^{15}$ en la

\footnotetext{
${ }^{14}$ Artículo 23. Los tratados, pactos y convenciones relativos a derechos humanos, suscritos y ratificados por Venezuela, tienen jerarquía constitucional y prevalecen en el orden interno, en la medida en que contengan normas sobre su goce y ejercicio más favorables a las establecidas en esta Constitución y en las leyes de la República, y son de aplicación inmediata y directa por los tribunales y demás órganos del Poder Público. Véase sobre esta norma BREWer-CARÍAs, Allan R. "Nuevas reflexiones sobre el papel de los tribunales constitucionales en la consolidación del Estado democrático de derecho: defensa de la Constitución, control del poder y protección de los derechos humanos", en Anuario de Derecho Constitucional Latinoamericano, $13^{\text {er }}$ año, Tomo I, Programa Estado de Derecho para Latinoamérica, Fundación Konrad Adenauer, Montevideo 2007, pp. 63 a 119.

15 Véase en Revista de Derecho Público, Nos. 93-96, Editorial Jurídica Venezolana, Caracas 2003, pp. 136 y ss.
} 
cual había precisado que el artículo 23 constitucional, "se refiere a normas que establezcan derechos, no a fallos o dictámenes de instituciones, resoluciones de organismos, etc., prescritos en los Tratados, (cursivo de la Sala) sino sólo a normas creativas de derechos humanos", es decir,

"que se trata de una prevalencia de las normas que conforman los Tratados, Pactos y Convenios (términos que son sinónimos) relativos a derechos humanos, pero no de los informes u opiniones de organismos internacionales, que pretendan interpretar el alcance de las normas de los instrumentos internacionales, ya que el artículo 23 constitucional es claro: la jerarquía constitucional de los Tratados, Pactos y Convenios se refiere a sus normas, las cuales, al integrarse a la Constitución vigente, el único capaz de interpretarlas, con miras al Derecho Venezolano, es el juez constitucional, conforme al artículo 335 de la vigente Constitución, en especial, al intérprete nato de la Constitución de 1999, y, que es la Sala Constitucional, y así se declara”. (...)

De lo anterior resulta entonces la afirmación de la Sala de que es ella la que tiene el monopolio en la materia de aplicación en el derecho interno de los tratados internacionales mencionados, contradiciendo el texto del artículo 23 de la Constitución que dispone que dichos tratados "son de aplicación inmediata y directa por los tribunales y demás órganos del Poder Público”, afirmando, al contrario, que ella es la única instancia judicial llamada a determinar "cuáles normas sobre derechos humanos de esos tratados, pactos y convenios, prevalecen en el orden interno"; competencia esta última que supuestamente emanaría "de la Carta Fundamental" -sin decir de cuál norma- afirmando que la misma "no puede quedar disminuida por normas de carácter adjetivo contenidas en Tratados ni en otros textos Internacionales sobre Derechos Humanos suscritos por el país" (texto cursivo de la Sala). De lo contrario, llegó a afirmar la Sala en dicha sentencia, "se estaría ante una forma de enmienda constitucional en esta materia, sin que se cumplan los trámites para ello, al disminuir la competencia de la Sala Constitucional y trasladarla a entes multinacionales o transnacionales (internacionales), quienes harían interpretaciones vinculantes".

En definitiva, la Sala Constitucional decidió que las sentencias de los tribunales internacionales sobre derechos humanos no eran de aplicación inmediata en Venezuela, sino que a sus decisiones sólo "se les dará cumplimiento en el pais, conforme a lo que establezcan la Constitución y las leyes, siempre que ellas no contrarien lo establecido en el artículo 7 de la vigente Constitución", concluyendo que "a pesar del respeto del Poder Judicial hacia los fallos o dictámenes de esos organismos, éstos no pueden violar la Constitución de la República 
Bolivariana de Venezuela, así como no pueden infringir la normativa de los Tratados y Convenios, que rigen esos amparos u otras decisiones"; es decir, que si la Corte Interamericana, por ejemplo, "amparara a alguien violando derechos humanos de grupos o personas dentro del pais, tal decisión tendría que ser rechazada aunque emane de organismos internacionales protectores de los derechos humanos" (texto cursivo de la Sala).

Por tanto, no existe órgano jurisdiccional alguno por encima del Tribunal Supremo de Justicia, y si existiera, por ejemplo, en materia de integración económica regional o de derechos humanos, sus decisiones "no pueden menoscabar la soberanía del país, ni los derechos fundamentales de la República" (texto cursivo de la Sala), es decir, en forma alguna pueden contradecir las normas constitucionales venezolanas, pues de lo contrario "carecen de aplicación en el país" Así lo declaró la Sala.

\section{LA REITERACIÓN DE LA NEGACIÓN DEL CARÁCTER SUPRA-CONSTITUCIONAL}

DE LOS TRATADOS SOBRE DERECHOS HUMANOS AUN CUANDO CONTENGAN NORMAS SOBRE SU GOCE Y EJERCICIO MÁS FAVORABLES A LAS ESTABLECIDAS

\section{EN LA CONSTITUCIÓN}

Ahora, sobre la prevalencia en el orden interno de la Convención Americana sobre Derechos Humanos como tratado multilateral que tiene jerarquía constitucional, afirmó la Sala que ello es sólo, conforme al artículo 23 de nuestro texto fundamental, "en la medida en que contengan normas sobre su goce y ejercicio más favorables" a las establecidas en la Constitución; pasando entonces a juzgar sobre la constitucionalidad de la sentencia de la Corte Interamericana, comenzando por "determinar el alcance" del fallo "y su obligatoriedad".

Observó para ello la Sala que en dicho fallo se consideró como su "punto central":

"la presunta violación del derecho a ser elegido del ciudadano Leopoldo López, infringiendo el artículo 23 de la Convención Americana, en vista de que esta disposición exige en su párrafo 2 que la sanción de inhabilitación solo puede fundarse en una condena dictada por un juez competente, en un proceso penal".

Para analizar esta decisión, la Sala Constitucional comenzó por reiterar lo que antes había decidido en la sentencia No 1939 de 18 de diciembre de 2008 (caso: Estado Venezolano vs. Corte Interamericana de derechos Humanos, 
caso Magistrados de la Corte Primera de lo Contencioso Administrativo $)^{16}$ en el sentido de que la protección internacional que deriva de la Convención Americana es "coadyuvante o complementaria de la que ofrece el derecho interno de los Estados americanos", es decir, que la Corte Interamericana "no puede pretender excluir o desconocer el ordenamiento constitucional interno" que goza de supremacía.

La Sala, además, indicó que el artículo 23 de la Constitución antes citado, contrariando su expreso contenido según el cual "prevalecen en el orden interno" -incluyendo la Constitución-, "en la medida en que contengan normas sobre su goce y ejercicio más favorables a las establecidas en esta Constitución", indicó que:

"no otorga a los tratados internacionales sobre derechos humanos rango 'supraconstitucional,' por lo que, en caso de antinomia o contradicción entre una disposición de la Carta Fundamental y una norma de un pacto internacional, correspondería al Poder Judicial determinar cuál sería la aplicable, tomando en consideración tanto lo dispuesto en la citada norma como en la jurisprudencia de esta Sala Constitucional del Tribunal Supremo de Justicia, atendiendo al contenido de los artículos 7, 266.6, 334, 335, 336.11 eiusdem y el fallo número 1077/2000 de esta Sala". ${ }^{17}$

\section{LA INTERPRETACIÓN DE LA CONSTITUCIÓN CONFORME AL PROYECTO POLÍTICO DEL GOBIERNO Y EL RECHAZO A LOS VALORES UNIVERSALES SOBRE DERECHOS HUMANOS}

Adicionalmente la Sala se refirió a otro fallo anterior, No 1.309/2001, en el cual había considerado que "el derecho es una teoría normativa puesta al servicio de la política que subyace tras el proyecto axiológico de la Constitución”, de manera que la interpretación constitucional debe comprometerse

\footnotetext{
${ }^{16}$ Véase en Revista de Derecho Público, No 116, Editorial Jurídica venezolana, Caracas 2008, pp. 88 y ss. Véase sobre esa sentencia BreWER-CARÍAs, Allan R. "El juez constitucional vs. La justicia internacional en materia de derechos humanos", en Revista de Derecho Público, No 116, (julio-septiembre 2008), Editorial Jurídica Venezolana, Caracas 2008, pp. 249-260; y "La interrelación entre los Tribunales Constitucionales de America Latina y la Corte Interamericana de Derechos Humanos, y la cuestión de la inejecutabilidad de sus decisiones en Venezuela", en Armin von Bogdandy, Flavia Piovesan y Mariela Morales Antonorzi (Coodinadores), Direitos Humanos, Democracia e Integracao Jurídica na América do Sul, umen Juris Editora, Rio de Janeiro 2010, pp. 661-701.

${ }^{17}$ Se refiere de nuevo la Sala a la sentencia de 22 de septiembre de 2000 (Caso Servio Tulio León Briceño), en Revista de Derecho Público, No 83, Editorial Jurídica Venezolana, Caracas 2000, pp. 247 y ss.
} 
"con la mejor teoría política que subyace tras el sistema que se interpreta o se integra y con la moralidad institucional que le sirve de base axiológica (interpretatio favor Constitutione)". Por supuesto, dicha "política que subyace tras el proyecto axiológico de la Constitución" o la "teoría política que subyace" tras el sistema que le sirve de "base axiológica", no es la que resulta de la Constitución propia del "Estado democrático social de derecho y de justicia”, que está montado sobre un sistema político de separación de poderes, democracia representativa y libertad económica, sino el que ha venido definiendo el gobierno contra la Constitución y que ha encontrado eco en las decisiones de la propia Sala, como propia de un Estado centralizado, que niega la representatividad, montado sobre una supuesta democracia participativa controlada y de carácter socialista, ${ }^{18}$ declarando la Sala que los estándares que se adopten para tal interpretación constitucional "deben ser compatibles con el proyecto político de la Constitución”-que la Sala no deja de llamar como el del "Estado Democrático y Social de Derecho y de Justicia", precisando que:

"no deben afectar la vigencia de dicho proyecto con elecciones interpretativas ideológicas que privilegien los derechos individuales a ultranza o que acojan la primacía del orden jurídico internacional sobre el derecho nacional en detrimento de la soberanía del Estado". (texto cursivo de la Sala)

Concluyó así, la sentencia, que "no puede ponerse un sistema de principios supuestamente absoluto y suprahistórico por encima de la Constitución", siendo inaceptables las teorías que pretenden limitar "so pretexto de valideces universales, la soberanía y la autodeterminación nacional" (texto cursivo de la Sala).

De allí concluyó la Sala reiterando lo que ya había ya decidido en la sentencia de 5 de agosto de 2008, No 1.265/2008 ${ }^{19}$ (Caso: ----) en el sentido de que en

\footnotetext{
${ }^{18}$ En los últimos años puede decirse que es la doctrina política socialista, la cual, por supuesto, no está en ninguna parte de la Constitución, y cuya inclusión en la Constitución fue rechazada por el pueblo en la rechazada reforma constitucional de 2007 (Véase BREWER-CARÍAS, Allan R. "La reforma constitucional en Venezuela de 2007 y su rechazo por el poder constituyente originario", en José Ma. Serna de la Garza (Coordinador), Procesos Constituyentes contemporáneos en América latina. Tendencias y perspectivas, Universidad Nacional Autónoma de México, México 2009, pp. 407-449). La Sala Constitucional, incluso, ha construido la tesis de que la Constitución de 1999 ahora "privilegia los intereses colectivos sobre los particulares o individuales", habiendo supuestamente cambiado "el modelo de Estado liberal por un Estado social de derecho y de justicia" (sentencia de 5 de agosto de 2008, № 1.265/2008, http:// www.tsj.gov.ve:80/decisiones/scon/Agosto/1265-050808-05-1853.htm) cuando ello no es cierto, pues el Estado social de derecho ya estaba en la Constitución de 1961.

${ }^{19}$ Véase en http://www.tsj.gov.ve:80/decisiones/scon/Agosto/1265-050808-05-1853.htm
} 
caso de evidenciarse una contradicción entre la Constitución y una convención o tratado internacional, "deben prevalecer las normas constitucionales que privilegien el interés general y el bien común, debiendo aplicarse las disposiciones que privilegien los intereses colectivos...(...) sobre los intereses particulares..."

En el fallo de la Sala Constitucional, la misma también hizo referencia al antes indicado fallo anterior No 1309/2001, donde se había referido al mismo tema de la interpretación constitucional condicionada "ideológicamente" que debe realizarse conforme a "mejor teoría política que subyace tras el proyecto axiológico de la Constitución" ya que la misma, como derecho, está "puesta al servicio de una política", no debiendo la interpretación verse afectada por "elecciones interpretativas ideológicas que privilegian los derechos individuales a ultranza o que acojan la primacía del orden jurídico internacional sobre el Derecho Nacional en detrimento de la soberanía del Estado". De ello concluyó la Sala que "la opción por la primacía del Derecho Internacional es un tributo a la interpretación globalizante y hegemónica del racionalismo individualista" siendo "la nueva teoría" el "combate por la supremacía del orden social valorativo que sirve de fundamento a la Constitución"; afirmando que en todo caso, "el carácter dominante de la Constitución en el proceso interpretativo no puede servir de pretexto para vulnerar los principios axiológicos en los cuales descansa el Estado Constitucional venezolano" (textos cursivos de la Sala).

En la sentencia No 1309/2001 la Sala también había afirmado que "el ordenamiento jurídico conforme a la Constitución significa, en consecuencia, salvaguardar a la Constitución misma de toda desviación de principios y de todo apartamiento del proyecto que ella encarna por voluntad del pueblo", procediendo a rechazar todo "sistema de principios supuestamente absoluto y suprahistórico, por encima de la Constitución”, y que la interpretación pueda llegar "a contrariar la teoría política propia que sustenta”. Por ello, la Sala negó la validez universal de los derechos humanos, es decir, negó "cualquier teoría propia que postule derechos o fines absolutos", o cualquier "vinculación ideológica con teorias que puedan limitar, so pretexto de valideces universales, la soberanía y la autodeterminación nacional" (texto cursivo de la Sala).

\section{EL ANÁLISIS DEL TEMA DE FONDO SOBRE LAS INHABILITACIONES POLÍTICAS IMPUESTAS POR AUTORIDADES ADMINISTRATIVAS Y EL RECHAZO AL PRINCIPIO DE QUE LAS MISMAS SÓLO PUEDEN SER IMPUESTAS POR DECISIÓN JUDICIAL}

Con base en lo anterior, al entrar a considerar el "punto central" de la sentencia de la Corte Interamericana sobre la violación del derecho a ser elegido 
del ciudadano Leopoldo López, por la inhabilitación administrativa dictada en su contra conforme al artículo 105 de la Ley Orgánica de la Contraloría General de la República y del Sistema Nacional de Control Fiscal, la Sala pasó a referirse a su propia sentencia antes mencionada, la No 1.265/2008 dictada el 5 de agosto de $2008,{ }^{20}$ cuando al decidir sobre una denuncia de inconstitucionalidad de dicha norma por violentar precisamente lo dispuesto en el artículo 23.2 de la Convención Americana, observó que conforme a dicha norma, se admite la “'reglamentación` de los derechos políticos mediante ley, incluso en atención a razones de 'condena, por juez competente, en proceso penal', no aludiendo la misma 'a restricción en el ejercicio de estos derechos, sino a su reglamentación', destacando, sin embargo, que de una manera general, el artículo 30 de la Convención Americana 'admite la posibilidad de restricción, siempre que se haga conforme a leyes que se dictaren por razones de interés general y con el propósito para el cual han sido establecidas'”. Concluyó la Sala que es posible, de conformidad con la Convención Americana "restringir derechos y libertades, siempre que sea mediante ley, en atención a razones de interés general, seguridad de todos y a las justas exigencias del bien común".

Ahora, al resolver la posible antinomia entre el artículo 23.2 de la Convención Interamericana y la Constitución, la Sala señaló que "la prevalencia del tratado internacional no es absoluta ni automática" siendo sólo posible si el mismo cuando se refiere a derechos humanos, contenga "normas más favorables a las de la Constitución", pasando a preguntarse la propia Sala sobre cuál debían ser los valores que debían tener presente "para determinar cuándo debe considerarse que esa disposición convencional es más favorable que la normativa constitucional interna", siendo su respuesta los supuestos valores derivados del proyecto político subyacente en la Constitución antes mencionado.

De ello concluyó sobre el fondo del tema resuelto por la Corte Interamericana que "la restricción de los derechos humanos puede hacerse conforme a las leyes que se dicten por razones de interés general, por la seguridad de los demás integrantes de la sociedad y por las justas exigencias del bien común", no pudiendo el artículo 23.2 de la Convención Americana "ser invocado aisladamente, con base en el artículo 23 de la Constitución Nacional, contra las competencias y atribuciones de un Poder Público Nacional, como lo es el Poder Ciudadano o

${ }^{20}$ Véase en http://www.tsj.gov.ve:80/decisiones/scon/Agosto/1265-050808-05-1853.htm 
Moral". En la citada sentencia No 1.265/2008 dictada el 5 de agosto de 2008, la Sala entonces concluyó que:

"En concreto, es inadmisible la pretensión de aplicación absoluta y descontextualizada, con carácter suprahistórico, de una norma integrante de una Convención Internacional contra la prevención, investigación y sanción de hechos que atenten contra la ética pública y la moral administrativa (artículo 271 constitucional) y las atribuciones expresamente atribuidas por el Constituyente a la Contraloría General de la República de ejercer la vigilancia y fiscalización de los ingresos, gastos y bienes públicos (art. 289.1 eiusdem); y de fiscalizar órganos del sector público, practicar fiscalizaciones, disponer el inicio de investigaciones sobre irregularidades contra el patrimonio público, e 'imponer los reparos y aplicar las sanciones administrativas a que haya lugar de conformidad con la ley' (art. 289.3 eiusdem). En tal sentido, deben prevalecer las normas constitucionales que privilegian el interés general y el bien común, debiendo aplicarse las disposiciones que privilegian los intereses colectivos involucrados en la lucha contra la corrupción sobre los intereses particulares de los involucrados en los ilícitos administrativos; y así se decide".

Finalmente, después de copiar in extenso el Voto concurrente del Magistrado Diego García-Sayán a la sentencia de la Corte Interamericana, la Sala Constitucional indicó pura y simplemente que "aunque coincide casi en su totalidad con el enfoque alternativo del Magistrado García-Sayán, no puede compartir, por los argumentos vertidos en los fallos referidos supra, la conclusión de que la sanción de inhabilitación sólo puede ser impuesta por una "autoridad judicial".

Sobre este punto, que es precisamente, el tema decidendum en la sentencia de la Corte Interamericana, la Sala Constitucional se refirió de nuevo a su sentencia No 1.265/2008, en la cual resolvió que en Venezuela, "en atención a la prevención, investigación y sanción de los hechos que atenten contra la ética pública y la moral administrativa (art. 274 Constitución), el Poder Ciudadano está autorizado para ejercer un poder sancionador sustancialmente análogo al derecho penal, incluyendo sanciones como las accesorias del artículo 105, cuyo objetivo es la protección del orden social general" (destacado nuestro); llegando a afirmar que "la incapacitación para ejercer diversos empleos', lo cual podría jurídicamente derivarse de una sentencia, pero también de una sanción administrativa" (texto cursivo de la Sala), concluyendo entonces con su afirmación infundada y falsa de que el artículo 65 del Constitución al señalar que 
"no podrán optar a cargo alguno de elección popular quienes hayan sido condenados o condenadas por delitos cometidos durante el ejercicio de sus funciones, [...] no excluye la posibilidad de que tal inhabilitación pueda ser establecida, bien por un órgano administrativo stricto sensu o por un órgano con autonomía funcional, como es, en este caso, la Contraloría General de la República”.

Ello, por supuesto, es totalmente errado, pues la restricción constitucional al ejercicio de derechos políticos es de interpretación estricta. Es por tanto errado señalar como lo hizo la Sala para llegar a esta conclusión que como la norma "plantea que la prohibición de optar a un cargo público surge como consecuencia de una condena judicial por la comisión de un delito", supuestamente ello no "impide que tal prohibición pueda tener un origen distinto". Ello es errado, pues de lo contrario no habría sido necesario establecer la restricción en la norma constitucional, siendo también errada la conclusión de que la norma sólo habría planteado "una hipótesis", y por tanto "no niega otros supuestos análogos". Esto es contrario al principio de que las restricciones a los derechos políticos establecidas en la Constitución, son sólo las establecidas en la Constitución, cuando es la propia Constitución la que no ha dejado la materia a la regulación del legislador.

Por tanto, es errada la conclusión de la Sala en el sentido de que supuestamente tratándose de un asunto de "política legislativa", sea al legislador al cual correspondería asignarle orientación al ius puniendi del Estado, de manera que "negar esta posibilidad significaría limitar al órgano legislativo en su poder autonómico de legislar en las materias de interés nacional, según lo prescribe el artículo 187, cardinal 1, en concordancia con el 152, cardinal 32 del Texto Fundamental". ${ }^{21}$

Al contrario, la política legislativa para el desarrollo del ius puniendi tiene que estar enmarcada en la Constitución, cuando sea la Constitución la que remita al legislador para ello. Sin embargo, cuando la Constitución establece que la restricción al ejercicio de un derecho político como el derecho al sufragio pasivo sólo puede limitarse por condena penal mediante decisión judicial, ello implica sólo eso, no pudiendo el legislador establecer otras restricciones que sean impuestas por autoridades administrativas.

\footnotetext{
${ }^{21}$ La Sala adicionalmente citó en su sentencia $N^{o} 1.260$ del 11 de junio de 2002 (caso: Víctor Manuel Hernández y otro contra el artículo 38, parágrafo Segundo, 52, y 54 de la Ley para Promover y Proteger el Ejercicio de la Libre Competencia) en relación con el jus puniendi y la supuesta diferencia entre el derecho administrativo sancionador y el derecho pena, concluyendo que entre ambos "no existen diferencias de tipo material, sino que la gran diferencia es relativa al ámbito normativo".
} 


\section{La PONDERACIÓN ENTRE La CONVENCIÓN AMERICANA Y \\ OTROS TRATADOS INTERNACIONALES COMO LOS RELATIVOS A LA LUCHA \\ CONTRA LA CORRUPCIÓN}

Por otra parte, la Sala destacó que la Convención Americana no es el único tratado suscrito por Venezuela relativo a derechos humanos y, en consecuencia, de rango constitucional a tenor de lo previsto en el artículo 23 de la Constitución Nacional, que debe ser tomado en consideración para resolver sobre la ejecución del fallo de la Corte Interamericana, haciendo alusión específicamente a la Convención Interamericana contra la Corrupción de 1996, que obliga a los Estados Americanos a tomar las medidas apropiadas contra las personas que cometan actos de corrupción en el ejercicio de las funciones públicas o específicamente vinculados con dicho ejercicio, "sin exigir que tales medidas sean necesariamente jurisdiccionales" (destacado nuestro), concluyendo de las normas de esta Convención, que los "mecanismos modernos para prevenir, detectar, sancionar y erradicar las prácticas corruptas" (texto cursivo de la Sala) que deben desarrollar los Estados, a juicio de la Sala, "deben ser entendidos como aquellos que se apartan y diferencian de los tradicionales, que exigen una sentencia penal firme por la comisión de un delito", "sin que se pueda concluir del contenido de dicha disposición que las conductas cuestionadas deban ser necesariamente objeto de condena judicial" (destacados nuestro). La Sala enumeró, así en su sentencia los órganos encargados en los diversos países de la ejecución de la Convención, generalmente de orden administrativos, siendo ello atribuido en Venezuela, como "autoridad central", al Consejo Moral Republicano constituido por la Contraloría General de la República, la Fiscalía General de la República y la Defensoría del Pueblo.

En la sentencia la Sala también hizo referencia a la Convención de las $\mathrm{Na}$ ciones Unidas contra la Corrupción" suscrita en 2003, donde se hace refefrencia a la obligación de los Estados de "procurar evaluar periódicamente los instrumentos juridicos y las medidas administrativas pertinentes a fin de determinar si son adecuadas para combatir la corrupción" (subrayado de la sala). Concluyendo que "no existe limitación alguna a que se trate exclusivamente de tribunales", destacando que conforme al artículo 30.7 de dicha Convención se establece "la posibilidad de inhabilitar "por mandamiento judicial u otro medio apropiado y por un periodo determinado por su derecho interno" a los sujetos de corrupción" (subrayado del fallo); y que la previsión de sanciones distintas a las judiciales se reitera en las Disposiciones Finales de la misma Convención (Capítulo VIII, artículo 65). 
De todo ello, la Sala Constitucional en su sentencia No 1.547 (Caso Estado Venezolano vs. Corte Interamericana de Derechos Humanos) de fecha 17 de octubre de 2011, concluyó que:

"aun si se pretendiera otorgar un sentido literal y restrictivo al artículo 23 de la Convención Interamericana, impidiendo la inhabilitación de un ciudadano para el ejercicio de cargos públicos por razones de corrupción, limitando la posibilidad de sanción a una sentencia judicial; podemos advertir que tal Tratado no es el único que forma parte integrante del sistema constitucional venezolano según el artículo 23 de nuestra Carta Fundamental. La prevalencia de las normas que privilegien el interés general y el bien común sobre los intereses particulares dentro de un Estado social de derecho y de justicia obligan al Estado venezolano y a sus instituciones a aplicar preferentemente las Convenciones Interamericana y de la ONU contra la corrupción y las propias normas constitucionales internas, que reconocen a la Contraloría general de la República como un órgano integrante de un Poder Público (Poder Ciudadano) competente para la aplicación de sanciones de naturaleza administrativa, como lo es la inhabilitación para el ejercicio de cargos públicos por hechos de corrupción en perjuicio de los intereses colectivos y difusos del pueblo venezolano".

Sin embargo, ante este pronunciamiento dictado con motivo de ejercer el control de constitucionalidad de la sentencia de la Corte Interamericana, la Sala Constitucional se apresuró a afirmar, que

"no se trata de interpretar el contenido y alcance de la sentencia de la Corte Interamericana de Derechos Humanos, ni de desconocer el tratado válidamente suscrito por la República que la sustenta o eludir el compromiso de ejecutar las decisiones según lo dispone el artículo 68 de la Convención Interamericana de Derechos Humanos".

No, de eso no se trata, sino que, a juicio de la Sala, de lo que se trata es:

"de aplicar un estándar mínimo de adecuación del fallo al orden constitucional interno, lo cual ha sucedido en otros casos y ejercer un 'control de convencionalidad' respecto de normas consagradas en otros tratados internacionales válidamente ratificados por Venezuela, que no fueron analizados por la sentencia de la Corte Interamericana de Derechos Humanos del 1 de septiembre de 2011, como lo son las consagradas en la Convención Interamericana contra la Corrupción y la Convención de las Naciones Unidas contra la Corrupción". 
Y ha sido precisamente ello, lo que supuestamente habría "obligado" a la Sala Constitucional "a ponderar un conjunto de derechos situados en el mismo plano constitucional y concluir en que debe prevalecer la lucha contra la corrupción como mecanismo de respeto de la ética en el ejercicio de cargos públicos, enmarcada en los valores esenciales de un Estado democrático, social, de derecho y de justicia", y decidir indicando que "no puede ejercerse una interpretación aislada y exclusiva de la Convención Americana de Derechos Humanos sin que con ello se desconozca el "corpus juris del Derecho Internacional de los Derechos Humanos", a los que ha aludido la propia Corte Interamericana en la sentencia del 24 de noviembre de 2004, caso: Trabajadores Cesados del Congreso vs. Perú, sus Opiniones Consultivas de la CIDH No OC-16/99 y No OC-17/2002.

\section{La DENUNCIA DE USURPACIÓN CONTRA La CORTE INTERAMERICANA Y LA DECLARACIÓN DE “INEJECUCIÓN” DE SU SENTENCIA}

Finalmente la Sala Constitucional acusó a la Corte Interamericana de Derechos Humanos de persistir

"en desviar la teleología de la Convención Americana y sus propias competencias, emitiendo órdenes directas a órganos del Poder Público venezolano (Asamblea Nacional y Consejo Nacional Electoral), usurpando funciones cual si fuera una potencia colonial y pretendiendo imponer a un país soberano e independiente criterios políticos e ideológicos absolutamente incompatibles con nuestro sistema constitucional".

De lo cual concluyó declarando

“inejecutable el fallo de la Corte Interamericana de Derechos Humanos, de fecha 1 de septiembre de 2011, en el que se condenó al Estado Venezolano, a través "de los órganos competentes, y particularmente del Consejo Nacional Electoral (CNE)", a asegurar "que las sanciones de inhabilitación no constituyan impedimento para la postulación del señor López Mendoza en el evento de que desee inscribirse como candidato en procesos electorales"; anuló las Resoluciones del 24 de agosto de 2005 y 26 de septiembre de 2005, dictadas por el Contralor General de la República, por las que inhabilitaron al referido ciudadano al ejercicio de funciones públicas por el período de 3 y 6 años, respectivamente; se condenó a la República Bolivariana de Venezuela al pago de costas y a las adecuación del artículo 105 de la Ley Orgánica de la Contraloría General de la República y el Sistema Nacional de Control Fiscal". 
Es decir, la Sala resolvió que la sentencia de la Corte Interamericana en su conjunto, es inejecutable en Venezuela, con la advertencia -cínica, por lo demás-, de que, sin embargo:

"la inhabilitación administrativa impuesta al ciudadano Leopoldo López Mendoza no le ha impedido, ni le impide ejercer los derechos políticos consagrados en la Constitución. En tal sentido, como todo ciudadano, goza del derecho de sufragio activo (artículo 63); del derecho a la rendición de cuentas (artículo 66); derecho de asociación política (el ciudadano López Mendoza no sólo ha ejercido tal derecho, sino que ha sido promotor y/o fundador de asociaciones y partidos políticos); derecho de manifestación pacífica (el ciudadano López Mendoza ha ejercido ampliamente este derecho, incluyendo actos de proselitismo político); así como, el derecho a utilizar ampliamente los medios de participación y protagonismo del pueblo en ejercicio de su soberanía (artículo 70), incluyendo las distintas modalidades de participación 'referendaria', contempladas en los artículos 71 al 74 eiusdem, en su condición de elector”.

Se destaca, sin embargo, que la Sala Constitucional no mencionó en esta enumeración de "los derechos políticos consagrados en la Constitución" ni el derecho pasivo al sufragio (el derecho a ser electo para cargos públicos), ni el derecho a ejercer cargos públicos, que son precisamente los que le impide ejercer la decisión de la Contraloría General de la República y violando lo previsto en la Convención Americana y en la propia Constitución, procedió a "aclarar" lo que no requería aclaratoria, en el sentido de que:

"la inhabilitación administrativa difiere de la inhabilitación política, en tanto y en cuanto la primera de ellas sólo está dirigida a impedir temporalmente el ejercicio de la función pública, como un mecanismo de garantía de la ética pública y no le impide participar en cualquier evento político que se realice al interior de su partido o que convoque la llamada Mesa de la Unidad Democrática”.

Ello no requería "aclararse", pues es bien evidente que las decisiones de la Contraloría o del Estado a través de cualquiera de sus órganos no le puede impedir a un ciudadano poder participar en los eventos políticos internos de las asociaciones políticas o a las cuales pertenezca o en eventos por estas convocados, de manera que la "aclaratoria" no es más que una deliberada expresión de confusión por parte de la Sala; y más aún con la frase final de la decisión que adoptó (dispositivo No 2), luego de declarar inejecutable la sentencia de la Corte Interamericana en el sentido decidir que: 
“2) La Sala declara que el ciudadano Leopoldo López Mendoza goza de los derechos políticos consagrados en la Constitución de la República Bolivariana de Venezuela, por tratarse solo de una inhabilitación administrativa y no política".

Sin embargo, como se dijo, antes había enumerado la Sala en forma expresa cuáles eran los derechos políticos que el Sr. López podía ejercer estando vigente la inhabilitación política que le había impuesto la Contraloría, refiriéndose la Sala expresamente sólo a el "derecho de sufragio activo (artículo 63); del derecho a la rendición de cuentas (artículo 66); derecho de asociación política '[...]; derecho de manifestación pacífica [...]; derecho a utilizar ampliamente los medios de participación y protagonismo del pueblo en ejercicio de su soberanía (artículo 70)", y derecho "de participación "referendaria" (artículos 71 al 74) "en su condición de elector". La Sala, por tanto se cuidó de no indicar que el Sr. López podía ejercer su derecho político al sufragio pasivo, derecho a ser electo y a ejercer cargos públicos electivos, que fueron precisamente los restringidos inconstitucionalmente por la Contraloría General de la República.

\section{LA INTERPRETACIÓN Y ACLARACIÓN DE LA SENTENCIA DE LA SALA CONSTITUCIONAL EN FORMA EX POST FACTO Y EXTRA PROCESO, MEDIANTE “COMUNICADO DE PRENSA" POR PARTE DE LA PRESIDENTA DE LA SALA CONSTITUCIONAL}

Sin embargo, el mismo día en el cual se publicó la sentencia de la Sala Constitucional, la presidenta del Tribunal Supremo de Justicia y de dicha Sala, expresó mediante un "Comunicado de Prensa" 22 un criterio distinto al que se había expuesto en la sentencia, agregando mayor confusión sobre sus efectos, y en particular sobre los derechos políticos que supuestamente podía ejercer el Sr. López.

Dicha presidenta del Tribunal Supremo, en efecto, comenzó por expresar, al referirse a la sentencia de la Sala Constitucional "que declaró inejecutable el fallo de la Corte Interamericana de Derechos Humanos" que había condenado al Estado venezolano, primero, que "los convenios suscritos por la República

\footnotetext{
${ }^{22}$ Véase Nota de Prensa del Tribunal Supremo: "Es inejecutable que Venezuela retroceda en sus avances en la lucha contra la corrupción" Afirmó la presidenta del TSJ; magistrada Luisa Estella Morales Lamuño, Autor: Redacción TSJ, Fecha de publicación: 17/10/2011. Véase en http://www.tsj.gov.ve/ informacion/notasdeprensa/notasdeprensa.asp? $\operatorname{codigo}=8848$
} 
Bolivariana de Venezuela no pueden tener carácter supra constitucional, pues sus disposiciones deben ajustarse y enmarcarse en los postulados de la Carta Magna"; y que "Venezuela no puede retroceder en los avances que ha logrado en la lucha contra la corrupción", asegurando entre otras cosas, "que las sanciones de inhabilitación no constituyan impedimento para la postulación de Leopoldo López Mendoza en eventos electorales" (texto cursivo es nuestro).

Ahora bien, frente a esta afirmación de que las sanciones de inhabilitación "no constituyan impedimento para la postulación en eventos electorales", la pregunta elemental es ¿cómo puede, en efecto, pensarse que alguien pueda tener derecho a postularse para la elección de un cargo electivo de representación popular, sin tener derecho a poder ejercer dicho cargo porque se lo impide la Contraloría General de la República? Lo que dijo la señora presidenta de la Sala Constitucional, ni más ni menos es como decir, que una persona inhabilitada para ejercer cargos públicos, sin embargo, puede postularse para ser electo para un cargo público, pero una vez electo no puede ejercer dicho cargo para el cual fue electo.

La postulación a un cargo de elección popular no es sino la primera fase del ejercicio del derecho pasivo al sufragio que implica además de la postulación, el derecho a ser elegido, y en caso de que así ocurra, el derecho a ejercer el cargo para el cual fue electo. De resto, no es más que una cómica situación la que informó la señora presidenta del Tribunal Supremo: que una persona inhabilitada para ejercer cargos públicos por la Contraloría, puede postularse para cargos de elección popular, y por tanto, con la posibilidad de salir electo, pero para nada, pues no puede ejercer el cargo porque ha sido inhabilitado.

Expresó en efecto, la señora presidenta del Tribunal Supremo que:

“del análisis realizado por la Sala Constitucional el ciudadano López Mendoza goza de todos sus derechos políticos, por lo que puede elegir y ser elegido en los eventos electorales en los que decida participar".

Y reiteró que "la Constitución de la República Bolivariana de Venezuela es profundamente garantista, y que salvaguarda los derechos políticos de la ciudadanía" precisando que "Leopoldo López Mendoza sí goza de todos sus derechos políticos, tal como lo expresa el dictamen (sic)".

Ello es por supuesto, totalmente falso, y lo que pone en evidencia, para ser benevolentes, es que, por lo visto, la presidenta no leyó lo que efectivamente dijo en la sentencia que firmó, pues la misma no incluyó -inconstitucionalmente por lo demás- en su contenido y enumeración de los derechos polí- 
ticos que podía ejercer el Sr. López, al derecho a ser elegido (derecho pasivo al sufragio); es decir, se cuidó de decidir que el Sr. López no gozaba de todos sus derechos politicos.

Sin embargo, teniendo en cuenta la "interpretación” que hizo la señora presidenta del Tribunal Supremo de la sentencia, la conclusión era que se trató de una modificación, ex post facto, introducida mediante un "Comunicado de Prensa" a la sentencia dictada, indicando que el Sr. López sí puede ejercer su derecho pasivo al sufragio y si puede "ser elegido", pero aclarando a renglón seguido que una vez que resultare electo, si ese hubiese sido el caso, respecto al ejercicio del cargo para el cual resultare electo, ello sería una "situación futura derivada de tal participación" que "no estuvo en el análisis de la Sala, ya que no puede pronunciarse sobre hechos que no han ocurrido". Por lo que, si todo ello hubiese sucedido, ya estaba "avisado" el Sr. López de lo que le podía haber pasado. Más clara no podía ser esta modificación al fallo dictada por la Presidencia del Tribunal Supremo en el "Comunicado de Prensa", y como la Sala se atribuyó el poder de ejercer de oficio este control de constitucionalidad de las sentencias de la Corte Interamericana, nadie le hubiera tenido que requerir su futura y anunciada acción.

Crear mayor y deliberada confusión, era realmente imposible, ${ }^{23}$ al punto de que en el diario El Mundo de España del día 18 de octubre de 2011, la noticia se tituló así: "El Supremo venezolano permite que Leopoldo López sea candidato en 2012", precisándose sin embargo, en los subtítulos que: “El Tribunal aclara que el opositor sí puede presentarse a las elecciones; Lo que se ha rechazado es el fallo de la Corte Interamericana que condenaba al Estado por la 'inhabilitación' para ejercer cargos públicos de López; Por lo tanto, López puede ser candidato pero no se sabe si podrá ejercer. El Tribunal dijo

\footnotetext{
${ }^{23}$ Según se reseña en la patilla.com, la Contralora General de la República, en medio de la confusión, declaró el día 18 de octubre de 2011, que "el líder opositor Leopoldo López, uno de los aspirantes a ser candidato en las elecciones presidenciales del 7 de octubre del próximo año, no puede desempeñar ningún cargo público hasta 2014. No puede desempeñar cargos públicos, ni por elección, nombramiento, contrato ni designación. ¿El cargo de alcalde, de concejal, de presidente, de gobernador es un cargo público o no? Sí lo es, entonces (López) no puede desempeñar esos cargos públicos dijo Adelina González, Contralora General en funciones. En declaraciones a la televisión estatal, González descartó el supuesto "limbo" en el que quedó López luego de que la presidenta del Tribunal Supremo de Justicia (TSJ), Luisa Estella Morales, indicara que López se podía postular a las elecciones aunque evitando pronunciarse sobre qué ocurriría en caso de ser elegido. Véase "Según la Contralora si López se postula sería "un fraude a la Ley", en http://www.lapatilla.com/site/2011/10/18/segun-la-contralora-si-lopezse-postula-seria-un-fraude-a-la-ley/
} 
que aplicar aquel fallo infringiría las leyes nacionales”. ${ }^{24}$ En la nota de prensa publicada en este Diario se afirmó que:

"El Tribunal Supremo venezolano (TSJ) aclaró este lunes que la decisión de la Sala Constitucional de declarar no ejecutable un fallo de la Corte Interamericana de Derechos Humanos a favor de Leopoldo López no impide al político opositor presentar su candidatura a las elecciones presidenciales".

La presidenta del TSJ de Venezuela, Luisa Estella Morales, señaló que López se puede postular, pero el fallo de Corte Interamericana (CorteIDH), que obliga a suspender la inhabilitación administrativa del político para ejercer cargo público, es "inejecutable" porque no se pueden anular las decisiones de la Contraloría.

"Leopoldo López tiene pleno derecho a elegir y ser electo, puede concurrir ante el Consejo Nacional Electoral inscribirse y participar en cualquier elección que se realice (...) libremente puede hacerlo", aclaró Estella en una conferencia de prensa.

No obstante, subrayó que "son inejecutables en primer lugar la nulidad de las resoluciones administrativas de la Contraloría y también "la nulidad de los actos administrativos por los cuales se inhabilitó administrativamente al ciudadano Leopoldo López".

Preguntada sobre la posibilidad de que López fuera elegido en los comicios para la Presidencia, convocados para el 7 de octubre de 2012, Morales se excusó de pronunciarse "acerca de situaciones futuras".

"Llegará el momento de que si eso ocurriese tendríamos que pronunciarnos, pero en este momento es ciertamente una posición incierta y futura sobre la cual la Sala no podría pronunciarse", señaló.

Con esta "aclaratoria" a la decisión adoptada mediante declaraciones públicas dadas por la presidenta del Tribunal Supremo de Justicia, lo que hizo el Tribunal Supremo fue consolidar la incertidumbre y el desconcierto político en el país, dejando vigente la sanción de inhabilitación política que dictó la Contraloría General de la República contra el Sr. Leopoldo López y en lo que resultó una especie de crónica de una inhabilitación política anunciada, impuso el siguiente itinerario que podía desarrollarse en este caso entre 2011 y 2012:

Primero, en el texto de la sentencia, declaró que entre los derechos políticos que enumeró expresamente como los que podía ejercer el Sr. López no estaba el derecho pasivo al sufragio, es decir, el derecho a ser electo;

${ }^{24}$ Véase en http://www.elmundo.es/america/2011/10/17/venezuela/1318884331.html 
Segundo, sin embargo, en la "aclaratoria" a la sentencia que dictó la presidenta del Tribunal Supremo, la misma declaró que el Sr. López sí se podía postular para cargos electivos y tenía derecho a ser electo, lo que por si generó incertidumbre sobre si efectivamente gozaba o no tal derecho conforme a la sentencia de la Sala;

Tercero, lo anterior le planteaba al Sr. López la disyuntiva de participar o no en el proceso-elecciones primarias-para la selección del candidato presidencial de oposición, pero con la certeza de que si no lo hacía ello hubiera sido por su propia voluntad y no porque se lo hubiese "impuesto" la Sala;

Cuarto, si hubiese llegado a salir electo en las elecciones primarias, ello le hubiera planteado una nueva disyuntiva de postularse o no como candidato presidencial en la elección presidencial, pero si no lo hacía ello también hubiera sido por su propia voluntad y no porque se lo hubiese impuesto la Sala; y

Quinto, si hubiese llegado a ganar la elección presidencial, la posibilidad de que hubiese podido ejercer el cargo para el cual habría sido electo hubiera quedado entonces en manos del Tribunal Supremo de Justicia, el cual, en ese momento, y sólo en ese momento se pronunciaría sobre lo que al dictar su sentencia consideró como una "situación incierta y futura".

Posteriormente, para agregar algo más a la confusión e incertidumbre, la misma presidenta del Tribunal Supremo de Justicia en una entrevista de televisión, ratificó que la sentencia de la Corte Interamericana de Derechos Humanos "que ordena restituir los derechos políticos al ex alcalde del municipio Chacao del Estado Miranda, Leopoldo López, no puede ser cumplida por la justicia venezolana”, indicando, sin embargo, que dicho ciudadano contaba "con todos sus derechos políticos" lo que no era cierto, pues se le había negado el derecho pasivo al sufragio, agregando que podía "hacer campaña o fundar partidos, [pero] lo que no puede es ejercer cargos de administración pública". ${ }^{25}$

La presidenta del Tribunal Supremo indicó, además, que la sentencia de la Corte Interamericana confundía "la inhabilitación política con la inhabilitación administrativa", sin percatarse que cuando dicha "inhabilitación administrativa" impide a un funcionario electo ejercer el cargo para el cual fue electo, se convierte en una inhabilitación política; pues aunque la Magistrada parecía ignorarlo, el derecho a ejercer cargos públicos de elección

\footnotetext{
${ }^{25}$ Véase reportaje del programa "Dando y Dando transmitido por la estatal Venezolana de Televisión", realizado por Rafael Rodríguez, en El Universal, Caracas 8-11-2011. En http://www.eluniversal.com/ nacional-y-politica/111108/morales-no-podemos-levantar-inhabilitacion-adminstrativa-a-lopez
} 
popular es un derecho político. De manera que cuando se impone una sanción de inhabilitación administrativa que según la presidenta del Tribunal era "de otra naturaleza [pues] es para poder administrar o manejar fondos públicos”, y ello impide a un funcionario electo ejercer el cargo para el cual resultó electo, implica que se lo inhabilita políticamente.

La Corte Interamericana no "se basó en hechos que no correspondían a la realidad" como dijo la presidenta del Tribunal considerando que la Corte Interamericana había tratado "el caso del ciudadano Leopoldo López como si él estuviera inhabilitado políticamente y el señor Leopoldo López nunca estuvo inhabilitado políticamente, él tuvo una sanción de carácter administrativo que en Venezuela está perfectamente establecida".

En fin, ignorando el propio texto de su sentencia, la presidenta del Tribunal afirmó que la Corte Interamericana confundió "sin entrar a analizar lo que es el derecho interno venezolano, [...] dos tipos de inhabilitaciones diferentes", pues según la presidenta del Tribunal López podía "hacer campaña y fundar partidos, lo que no puede es ocupar cargos administrativos", y las actividades políticas que pueda hacer "no puede confundirse con las condiciones de elegibilidad ese es otro punto que no se ha presentado...”. Lo que no explicó la Presidenta del Tribunal es cómo puede decirse que una persona no está inhabilitada políticamente si pudiendo ser electa para ocupar un cargo ejecutivo (como el de Alcalde, Gobernador o Presidente) que implica administrar o manejar fondos, en definitiva, no lo puede ejercer el cargo para el cual fue electo cuando exista contra la misma una sanción de inhabilitación administrativa. ${ }^{26}$

De todo ello, lo que quedaba claro era que independientemente de si el Sr. López iba o podía resultar o no electo, respecto de él, y del propio futuro del país, la situación política subsiguiente no dependía de la voluntad del pueblo soberano, sino de la decisión de un Tribunal Supremo que además de usurpar el poder constituyente y rebelarse contra las decisiones del tribunal internacional encargado de la protección de los derechos humanos en América, se reservaba en definitiva el derecho de anular o no la voluntad popular de acuerdo con las circunstancias que se presentasen en el futuro.

Nueva York, junio 2012.

\footnotetext{
${ }^{26}$ Dijo la presidenta del Tribunal: "El ciudadano Leopoldo López no está inhabilitado políticamente ni ha estado; él puede ejercer todos sus derechos políticos, en Venezuela hay una gama de derechos políticos extensos, se fundan partidos, se puede hacer campaña electoral, se puede hacer cualquier tipo de gestión, ahora, eso no debe confundirse cuando se opta a un cargo de elección popular con las condiciones de elegibilidad".
} 